\title{
Parallel Integration and ASEAN-EU Trade Potential: an Empirical Analysis
}

\author{
Shahriar Kabir \\ Curtin University \\ Ruhul A Salim \\ Curtin University
}

\begin{abstract}
This paper empirically assesses the integration of ASEAN with the European Union (EU) from an ASEAN-European Union trade model, and investigates their untapped trade potential. For the observation period of 1996 to 2008, the ASEANEU trade gap between the potential trade and the actual trade appears quite substantial. This study opens up the scope for future study on the ASEAN-EU regional integration.
\end{abstract}

- JEL Classification: C23, F10, F15

- Keywords: Regional Integration, Intra-regional Trade, Gravity Model

\section{Introduction}

Regional integration has been a major research topic in international economics and finance over the last two decades. The initial focus was on the assessment of the monetary policy and currency integration potential of the European Union (EU), latter the research area further extends to cover the assessment of the success of the Euro as well as the investigation of the integration potential of other regions.

\footnotetext{
*Corresponding address: Ruhul A Salim; School of Economics \& Finance, Curtin Business School, Curtin University, Perth, WA 6845, Phone: +61 89266 4577, Fax: +61 89266 3026, E-mail: Ruhul.Salim @cbs.curtin.edu.au / Shahriar Kabir; University of Liberal Arts Bangladesh, 4/A, Satmasjid Road, Dhanmondi, Dhaka-1209, Bangladesh, Phone: +61 89266 4577, Fax: +61 89266 3026, E-mail: sh kabir@hotmail.com ○2011-Center for Economic Integration, Sejong Institution, Sejong University, All Rights Reserved.
} 
During this period, the East Asia, ASEAN, the South Mediterranean countries and the East African Community (EAC) appear as potential candidates for regional integration. Among these regions, economists such as Bayoumi and Eichengreen (1997) suggest that East Asia and ASEAN as highly credible candidates for a currency union after EU, although significant differences exist in the integration process between the EU and East Asia (Capannelli and Filippini, 2010). In recent years, ASEAN has shown remarkable success in their regional integration process. Besides the ASEAN Free Trade Agreement (AFTA), ASEAN members have developed some free trade areas outside the region. These areas include, ASEANRepublic of Korea Free Trade Area, ASEAN-Japan Free Trade Area, ASEANIndia Free Trade Area, ASEAN-China Free Trade Area and ASEAN-Australia New Zealand Free Trade Area. In addition, the region develops dialogue relations with Canada, the European Union, Russia, USA, and Pakistan. Most of the ASEAN extra-regional relations develop from four perspectives, namely economic and trade, political and security, social and cultural and development cooperation.

This paper assesses the possibilities of the ASEAN-EU trade integration by estimating the existing untapped trade potential between the two regions. For this analysis, four countries have been selected from the European Union, namely France, Germany, Italy and Spain and six members from ASEAN, namely Singapore, Indonesia, Malaysia, Thailand, the Philippines and Viet Nam. These selected members represent the major trade and GDP share of the respective regions. The analysis focuses on three main issues, such as the level of trade integration between ASEAN and the EU, untapped trade potential, and the pattern of the gap between the potential trade and the actual trade in these regions. This paper applies an "out-of-sample" method to measure the untapped trade potential between the two regions. The estimated EU trade model is used as a benchmark, and applied to the ASEAN-EU perspective. This paper uses data for the period of 1995 to 2008, which provides a recent scenario on the success and possibilities of ASEAN attempts for extra-regional trade integration with the European Union.

The rest of the paper is organized as follows: Section II provides an overview of ASEAN trade relation as well as a critical review of the existing literature on trade integration, followed by a description of the analytical framework in Section III. Model estimation and an analysis of empirical findings are discussed in Section IV. Concluding remarks are given in the final section. 


\section{An Overview on ASEAN-EU Trade and a Review of Literature}

\section{A. Overview: The ASEAN-EU trade relation}

The idea of regional cooperation was initiated with the European Coal and Steel Community (ECSC) in 1951. Belgium, West Germany, Luxembourg, France, Italy and the Netherlands were the members of the ECSC, which formed the European Atomic Energy Community (EURATOM) and the European Economic Community (EEC) for further integration. These three communities were combined to form a single Commission in 1967, which ultimately transformed into the European Union through the "Maastricht Treaty". The continuous process of integration resulted in a single market by the end of 1992, removing all trade barriers. In the same year, an economic and monetary union (EMU) was established among the members, which was managed by the European Central Bank (ECB). In 1999, the Euro was launched as the single currency as a successful outcome of regional economic integration, and the ECB was given the authority to develop a comprehensive monetary policy throughout the Euro area. Integration of the European monetary policy and currency has been regarded as highly successful. Rose (2000) and Glick and Rose (2002) suggest this impact has benefited regional integration and currency union. Frankel and Rose (2002), Nardis and Vicarelli (2003) and Berger and Nitsch (2008) assess the positive impact of common currency on trade.

Similarly, ASEAN has emerged as a strong candidate for regional integration in recent years. The Association of Southeast Asian Nations (ASEAN) was formed in 1967 with five nations, namely Indonesia, Malaysia, Philippines, Singapore, and Thailand. The objectives of the Association were to accelerate regional economic, social and cultural development, and to establish peace and stability through justice amongst its member nations. Later on, Brunei Darussalam, Vietnam, Laos, Myanmar and Cambodia joined the Association. The total area of the ASEAN region is 4.44 million square kilometers with a current population of about 584 million. In 2008, the total regional GDP for ASEAN was USD 1.5 trillion, with a per capita regional GDP of USD 2,580.6 and regional GDP growth of 4.4\%. The highest GDP for a participating member was Indonesia (USD 511 billion), followed by Thailand (USD 273 billion) and Malaysia (USD 222 billion). The highest per capita GDP was achieved by Singapore $(\$ 36,046)$, followed by Brunei Darussalam $(\$ 35,622)$ and Malaysia $(\$ 7,969)$. Out of the ten member countries, 
seven members achieved per capita GDP higher than $\$ 1000$, while four members attained $6 \%$ or higher GDP growth rate. Lao PDR attained the highest GDP growth in the region (8.4\%). Total ASEAN trade for 2008 was about USD 1.7 trillion (ASEAN Secretariat, 2008a, ASEAN Secretariat, 2008b).

ASEAN has made significant progress in developing intra- and extra-regional economic relationships. The vision of ASEAN leaders reflects the aspiration for greater cooperation within and outside the region. Richardson (2005) identifies ASEAN members as attractive trade partners for non-Asian countries. ASEAN gradually increases stability, prosperity and economic integration with other significant parts of Asia, which makes ASEAN as globally attractive for trade and investment. Keng Yong Ong, the ASEAN secretary General, mentions ASEAN as an important trade partner for the EU and emphasizes ASEAN-EU regional cooperation (Ong, 2008).

ASEAN has had longstanding trade relations with the EU members, though the formal FTA negotiation began in 2007. Figure 1 presents the ASEAN-EU trade relations from 1996 to 2008. This figure includes total annual exports and imports between six ASEAN members ${ }^{1}$ and four EU members. ${ }^{2}$

Figure 1. The ASEAN-EU trade relation

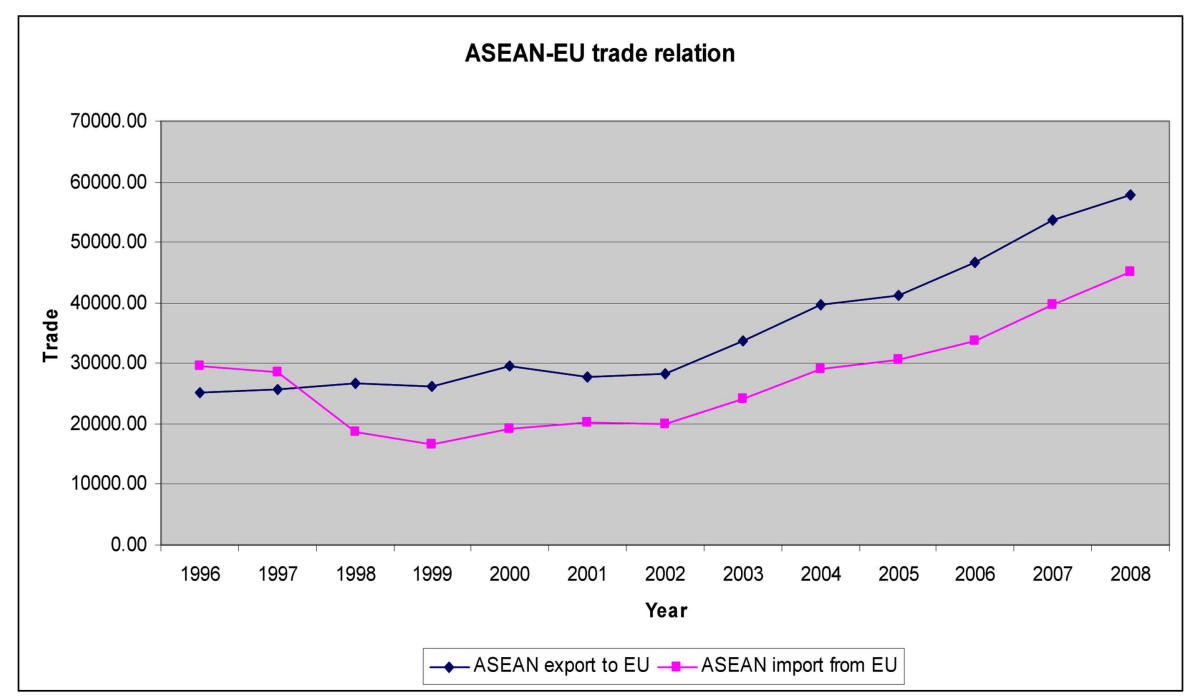

Source: Authors' calculation based on data provided in DATASTREAM

\footnotetext{
${ }^{1}$ Singapore, Indonesia, Malaysia, Thailand, Philippines and Viet Nam.

${ }^{2}$ France, Germany, Italy and Spain.
} 
Figure 2. ASEAN-EU trade to GDP comparison

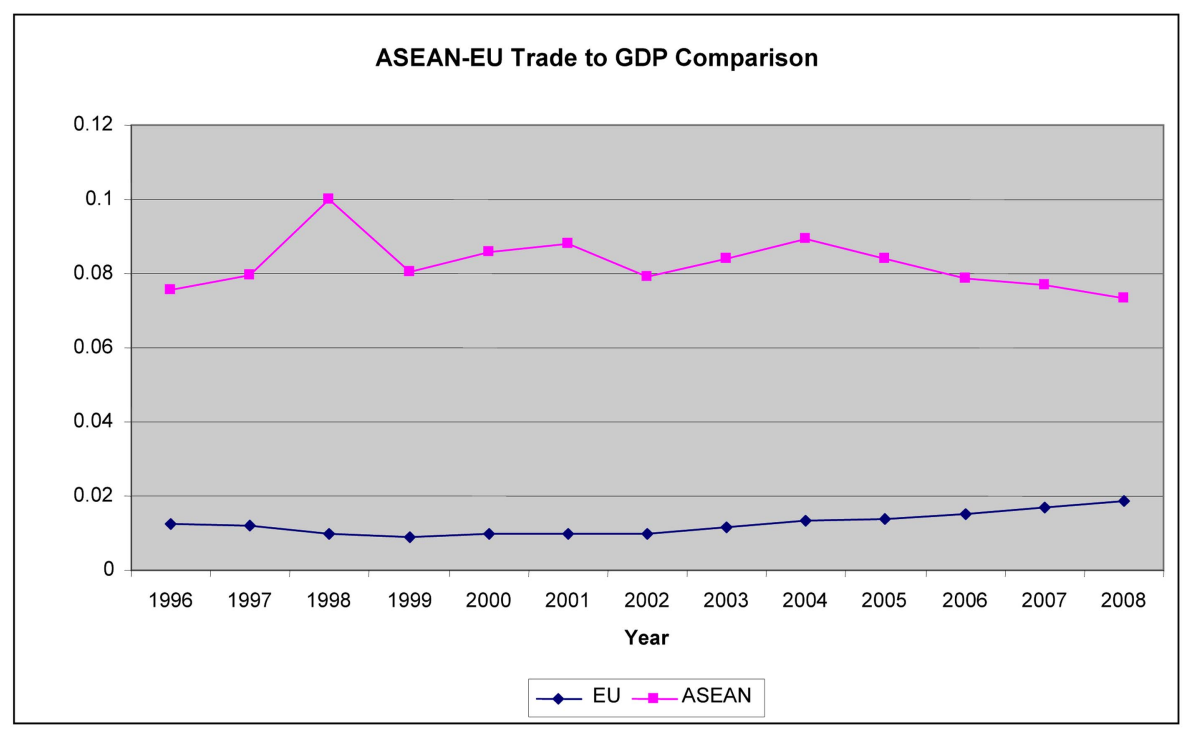

Source: Authors' calculation

From Figure 1, it is clearly evident that since 1998, ASEAN export to the EU leads ASEAN import from the EU. The rates of increase for both export and import become steeper since 2002. The gap between exports and imports throughout the period has been very consistent, though the gap has been increasing since 2007.

Figure 2 presents the total trade between the four EU members and the six ASEAN members each year as a percentage of GDP. ${ }^{3}$ This trade deepening ratio is calculated separately for both the EU GDP and the ASEAN GDP. The figure shows that the ASEAN-EU trade is $7 \%$ to $10 \%$ of ASEAN GDP, while it is only $2 \%$ or less of the EU GDP. Though the ASEAN economy is more dependent on ASEAN-EU trade than the EU economy, ASEAN dependency has been decreasing since 2004, and EU dependency has been increasing since 2002. This tendency for reverse movement requires an in-depth study of ASEAN-EU trade integration and its impact.

\footnotetext{
${ }^{3}$ Salim and Kabir (2010) mention the percentage of trade over GDP as "Trade deepening".
} 


\section{B. Literature review}

The importance on apposite exchange rate regimes for Asian countries after the 1997 Asian financial crisis initiated the need for regional economic integration in East Asia (Madhur, 2002). This realization is clearly reflected in ASEAN intra- and extra-regional trade integration.

The initial idea of the East Asian integration comes from the need for a sustainable monetary policy in the region. According to optimal currency area (OCA) theory, 'symmetry of shocks across countries', 'trade and financial integration', and 'labor mobility and wage flexibility' are among the important criteria to be considered for a regional currency union (Lee, Shin, and Park, 2004). Based on this theory, Bayoumi and Eichengreen (1997) mention East Asia as the most 'plausible candidate' for a currency union after the Euro area. Dutta (2002) explains the 2006 consensus between China, Japan and Korea as a significant step towards the development of the Asian Economic Community.

Many studies have included trade and financial linkages and similarity of business cycle to assess the aptness of East Asian currency union (for example, Kumakura, 2006, Lee, Shin, and Park, 2004 and Wang, 2004). Further, a number of studies mention the co-integration of financial markets as an effective step towards creating a regional market (Click and Plummer, 2005, Candelona, Piplacka and Straetmansb, 2008). Increased co-movement has been observed among these stock markets during the 'boom and bust'. However, ASEAN is still at a preliminary stage of the process of monetary union, and ratifying the free trade areas within the members and outside the region. The success of this intra- and extra-regional trade integration would set the economic integration path in the future.

Diverse opinion exists about ASEAN regional economic integration in the literature (Sally and Sen, 2005; Sally, 2006; Sen, 2006). The strength and credibility of the FTAs developed by ASEAN or its individual members is under question, even though the negotiations are WTO consistent. Apart from goods, ASEAN opportunity in services, investment, trade facilitation, regulatory cooperation and dispute settlement are also subject to consideration (Sen, 2006). Internal political and social complexities among ASEAN members act as important factors against effective and successful FTAs. Besides, the possibility exists for other ASEAN members to misinterpret the FTA strength of Singapore, which would in turn lead to development of weak and market distorting FTAs (Sally, 
2006 and Sally and Sen, 2005). Even after providing some better indications for FTAs, Thailand suffers from complications in the process and the level of policy directions. Pomfret (2007) also denies for many of the Asian agreements to have serious contents, though he agrees with the difficulties involved in measuring regionalism.

However, Richardson (2005) identifies ASEAN members as attractive trade partners for Australia and New Zealand. ASEAN gradually increases stability, prosperity and economic integration with other significant parts of Asia, which makes ASEAN globally attractive for trade and investment. Hashmi and Lee (2008) mention the current East Asian economic integration process as an effective step for unmarked trade liberalization process. They propose using initial flexible agreements for currency stabilization, followed by future stiff agreements. They argue that the market-driven economic integration suffers from limited institutional support in terms of Asia-wide FTAs, financial stabilization mechanism, intraregional exchange rate stabilization and 'provision of various types of regional public goods' (Hashmi and Lee, 2008: 121). Besides, the divergence in political and economic system slows down the institutional cooperation. This situation requires flexibility in the integration process until the political and economic structures strongly converge.

ASEAN policymakers often face difficulty of convincing different agencies regarding the benefit of trade and investment liberalization due to intensified external competition (Chai, 2011). Beside sustainability benefit of economic integration for weaker economies such as Cambodia and Laos is often questionable. However, the competitive trade and investment liberalization led by regionalism can be the preparation for consequent multilateral liberalization (Chai, 2007).

Kawai (2005) proposes more formal institutional mechanisms for trade and investment facilitation among East Asian members to meet their increased economic integration. He describes the East Asian regional integration under the multilateral liberalization framework and open regionalism. Initially in mid-1980s, Japanese FDI flow to East Asian economies played a vital role in this economy. Kawai (2005) estimates that, including Japan, intra-regional trade was $35 \%$ of total East Asian trade in 1980, increasing to 54\% in 2003. Excluding Japan, intraregional trade increased from $22 \%$ to $44 \%$ over the same period. Though this amount is above the intra-regional trade of the North American Free Trade Area (46\%), it is still lower than the intra-regional trade of EU-15 (64\%). Further, his estimated intra-East Asian trade intensity index is 2.2 (including or excluding 
Japan) in 2003, while the indices are 1.7 for EU and 2.5 for NAFTA. This implies a high degree of East Asian regional integration through trade, which is comparable to EU and NAFTA.

Rana (2006) re-estimates the measures of East Asian trade integration for 1980 to 2005 , and is not as optimistic as Kawai (2005). He finds an increase of $32.2 \%$ to $38.2 \%$ in intra-regional trade between ASEAN +3 countries during the period, which is lower than NAFTA (45\%) and EU-25 (66.2\%). Including Hong Kong, China and Taipei, this amount increased to $54.5 \%$. After adjustment for a country's or region's relative size, the trade intensity index appears steady at 2 since 1990. However, both studies (Kawai, 2005 and Rana, 2006) agree in the positive intraregional trade impact of the current integration process. However, few recent studies focus on extra-regional integration and trade impact for different regions (Pastore, Ferragina and Giovannetti, 2009), and there is a dearth of research on ASEAN. Hence, ample scope exists for a study on ASEAN extra-regional trade integration prospects.

In some recent literature, ASEAN-EU trade relations have been emphasized as having great importance. The initiation of ASEAN-EU trade integration occurred in April 2007 through the FTA negotiations (Andreosso-O'Callaghan, 2009). Since then, different and self contradictory opinions appear among economists about the trade relations between ASEAN and Europe. Ong (2008) mentions ASEAN as an important and reliable partner for Europe, while Capannelli and Filippini (2010) emphasizes the differences in the regional integration process between the EU and East Asia. The EU integration proceeds through strong formal and structural methods of institutionalization and policies, and the monetary union. On the other hand, East Asian integration proceeds through informal processes of production network, trade patterns and more recently financial cooperation.

In a study on Europe-Asia trade flow, Gavin and Sindzingre (2009) emphasize the European trade enhancement strategy with Asia and suggest the need for a stronger integration strategy. On the contrary, they question the sustainability of the trade growth due to increasing ASEAN exposure to extra-regional shocks. Similarly, Andreosso-O'Callaghan (2009) investigates the drawbacks of the ASEAN-EU FTA. In their analysis, based on opinions received from the ASEAN stakeholders, they focus on the cost of adjustment as the most critical risk for the ASEAN-EU FTA. Robles (2008) emphasizes the failure of the EU-Mercosur negotiation as an important lesson for ASEAN leaders in ASEAN-EU negotiation. He advises to consider the difference between the EU's rhetoric and the reality; as 
well as to consider ASEAN members' absorbability of any negative consequence. Unfortunately, these studies are conceptual and lack substantial empirical evidence. Plenty of scopes exist for empirical analysis of the ASEAN-EU trade potential.

The above discussion reviews the regional integration progress of ASEAN and investigates the possibilities of ASEAN-EU trade integration. From this discussion, it is evident that substantial conceptual discussion on the ASEAN-EU trade potential appears in the literature, though significant empirical evidence is lacking. This paper empirically investigates the ASEAN-EU trade potential and attempts to provide future policy recommendations.

\section{Analytical Framework}

\section{A. The gravity model specification}

Tinbergen (1962) and Pöyhönen (1963) successfully use a gravity model in estimating the trade between two countries as proportional to their product of masses (GDP) and inversely proportional to their distance. Anderson (1979) and Bergstrand $(1985,1989)$ show the 'theoretical foundation' of the model, while others strengthen the foundation from different perspectives (Helpman and Krugman, 1985, Deardorff, 1998, Eaton and Kortum, 2002, Anderson and Wincoop, 2003 and Kimura and Lee, 2006). Rose (2000) and Glick and Rose (2002) successfully implement the gravity model to estimate the impact of regional integration and currency union on trade.

This paper uses the coefficients of a gravity model of intra-EU trade estimated by Pastore, Ferragina and Giovannetti (2009) as consistent for the ASEAN-EU trade relation and applies these coefficients to the trade equations between four EU members (France, Germany, Italy and Spain) and six ASEAN members (Singapore, Malaysia, Indonesia, Thailand, Philippines and Viet Nam) to calculate the potential trade for the selected ASEAN-EU country pairs for the period of 1994 to 2008. Furthermore, the estimated potential trade amount is compared to the actual trade volume to assess the existing trade potential between ASEAN and the European Union and the possibility of future trade integration between these two regions.

The gravity model analyzes the trade gap between two countries based on trade enhancing elements (GDP) and trade resistance factors (distance), which can be considered as a "natural benchmark". Use of time invariant parameters and dummy 
coefficients in the panel data provides the opportunity to acquire additional country specific information. This paper uses the following gravity specification to obtain the estimates of intra-EU trade creation during their process of economic integration:

$$
Y_{i j t}=\alpha_{i j}+\beta_{1} P_{\text {op }}+\beta_{2} G D P P C_{i t}+\beta_{3} P_{0 p}+\beta_{4} G D P P C_{j t}+\beta_{5} D_{i s t}+\beta_{i j} C L B_{i j}+\beta_{7} C L_{i j}+U_{i j t}
$$

where $Y_{i j t}$ is the trade variable between country $i$ (reporting country) and country $j$ (trade partner) at time $t$; $P_{o p}\left(P_{i t}\left(p_{j t}\right)\right.$ is the population of country $i(j)$; GDPPC $\left(G D P P C_{j t}\right)$ is a measure of per capita income of country $i(j)$; Dist ${ }_{i j}$ is the geographical distance in km between the capital city of country $i$ and of country $j$; $\beta_{i}(i=1 \ldots \ldots \ldots 7)$ are parameters of the equation, and $U_{i j t}$ is a white noise disturbance term. All variables are in logs so the estimated coefficients are interpreted as elasticity. $C L B$ is a dummy used for common land border. Its value takes 1 , if the two countries share a common land border and 0 otherwise. $C L$ represents the common language, which takes a value of 1 if the trade partners speak the same language and 0 otherwise.

If the income level of local country $\left(G D P P C_{i}\right)$ increases, the purchasing power of the local country will increase. It will result in an increase in the reporting country's imports, the trade partner's exports and overall trade. Similarly, an increase in the target country's income level $\left(G D P P C_{j}\right)$ will result in an increase in the reporting country's exports, the trade partner's imports and overall trade. Distance has a negative impact on bilateral trade. Besides geographical remoteness, distance refers to "surface" of host markets, level of trade costs, and presence of home bias. The common land border dummy and the common language dummy capture the impact of culture, language, communication, information exchangeability and home biasness.

\section{B. Trade projection approach}

The estimated coefficients of gravity model relative to the intra-EU trade model are applied to the similar specifications of the ASEAN-EU trade model. ${ }^{4}$ Pastore, Ferragina and Giovannetti (2009) consider these estimated parameters as a "benchmark" to compare the potential integration between the Europe Agreements (EAs) and the Mediterranean Association Agreements (MAAs). This paper uses a

\footnotetext{
${ }^{4}$ ASEAN-EU trade model presents Exports and Imports of six ASEAN members with four EU members.
} 
similar benchmark to assess the undiscovered potential of ASEAN-EU trade integration.

The undiscovered trade potential of ASEAN-EU trade integration is estimated from the ratio of potential trade to actual trade. The projected potential trade is the amount of trade that can be achieved by ASEAN if they can achieve the level of regional trade integration as the EU. The ratio between the potential trade and the actual trade would indicate the level of ASEAN-EU trade integration compared to the intra-EU trade integration. The measure of trade potential can be expressed in the following relation:

$$
\text { Undiscovered Trade Potential }=\frac{\text { Estimated Potentia Trade }}{\text { Actual Trade }} \ldots . . .
$$

If the trade potential is higher than 1 , the existence of undiscovered trade possibilities between ASEAN-EU is evident. If the measure is at unity, actual trade has already met the potential trade level. The decreasing trends of trade potential indicate that the actual level of trade converges towards the potential trade level, while the increasing trends indicate the enhancement of gap between the actual trade level and the potential trade level.

\section{Data Sources and Empirical Analysis}

The first step of the analysis is the country selection for the study. For the European Union, the four selected members, France, Germany, Italy and Spain, trade between them above $50 \%$ of the total intra-regional trade which occurs among the 12 Euro members (for detail, see Salim and Kabir, 2010). For ASEAN, the ASEAN5 is selected along with Viet Nam as a rising star of the region. Trade data for both EU members and ASEAN members come from the United Nations (UN) trade database, while country GDP and population data are collected from the OECD database, Euro statistics and DATASTREAM. Distance between countries is calculated based on the country location provided by the CIA World Fact-book. Data for extra-regional trade between the EU and ASEAN is observed from 1994 to 2008. Trade potential is estimated separately for exports and imports for each country-pair. 
Table 1. Estimated coefficients for intra-EU model

\begin{tabular}{ccc}
\hline Coefficient & Elasticity & Significance level \\
\hline Const & 3.88 & Significant at $1 \%$ level \\
Lgdppc $_{\mathrm{i}}$ & 0.53 & Significant at $1 \%$ level \\
Lgdppc $_{\mathrm{j}}$ & 1.06 & Significant at $1 \%$ level \\
Lpop $_{\mathrm{i}}$ & 1.01 & Significant at $1 \%$ level \\
Lpop $_{\mathrm{j}}$ & 1.04 & Significant at $1 \%$ level \\
Ldist $_{\mathrm{ij}}$ & -0.61 & Significant at $1 \%$ level \\
$\mathrm{Cl}$ & 0.08 & Not significant \\
$\mathrm{Clb}$ & 0.47 & Significant at $1 \%$ level \\
\hline
\end{tabular}

\section{A. Intra-EU trade integration}

As mentioned above, the gravity model of intra-EU trade integration estimated by Pastore, Ferragina and Giovannetti (2009) is used in this paper for the elasticity of different variables. The results of their estimated model are as follows:

This result is used in this paper for two reasons. Firstly, Pastore, Ferragina and Giovannetti (2009) use the same set of countries from the European Union to assess the trade potential of MED members and CEECs with the EU. Hence, applying their intra-EU model to the ASEAN-EU trade model would provide an opportunity to compare the ASEAN-EU trade potential with the EU-MED and the EU-CEEC trade potential. Such a comparison would open up some important policy recommendations and future research directions. Secondly, the model is econometrically supported by using time variable and separate dummy variables for the exporting and the importing countries, as well as by satisfying the random effect estimation. The robustness is also checked in the model by applying total GDP instead of population.

The major variables of this model are significant and the signs are as expected. Coefficients for per capita GDP and population are positive for both the reporting country and the partner country, while the coefficient for distance between them is negative. This finding is consistent with the theory that higher GDP increases trade, while higher distance creates resistance. All these coefficients are significant at the $1 \%$ level. The common language dummy is found to be insignificant, while none of the AESAN-EU country pairs share common borders. Hence, these two variables are dropped from the ASEAN-EU trade model.

As this model estimates the variables in natural logarithms, the coefficients of the variables estimate the elasticity. According to the definition of elasticity, the 
estimated coefficients can be interpreted as a percentage change of trade due to a one percent change in each variable. Firstly, a $1 \%$ increase in the reporting country's per capita GDP would lead to an increase of $0.53 \%$ in trade between the reporting country and the partner country; while a $1 \%$ increase in the partner country's per capita GDP would increase trade by $1.06 \%$ between them. Secondly, a $1 \%$ increase in the reporting country's population would lead to an increase of $1.01 \%$ in trade between the reporting country and the partner country; while a $1 \%$ increase in the partner country's per capita GDP would increase trade by $1.04 \%$ between them. Finally, a $1 \%$ increase in distance between the reporting country and the partner country would decrease trade by $0.61 \%$ between the reporting country and the partner country.

These interpretations lead to the following ASEAN-EU trade model for calculating potential trade if they are having the intra-regional trade integration success similar to that of the EU members:

$$
Y_{i j t}=3.88+1.01 \text { Pop }_{i t}+0.53 G D P P C_{i t}+1.04 P_{o p} p_{i t}+1.06 G D P P C_{j t}-0.61 D_{i s t} t_{i j}+U_{i j t}
$$

\section{B. ASEAN-EU trade integration}

The major objective of this paper is to assess the undiscovered potential of the ASEAN-EU trade integration. Our methodological approach is to estimate the potential trade, which would be made possible if the ASEAN-EU trade had a level of trade integration similar to the intra-EU trade, and to compare the potential trade with the actual trade that takes place between ASEAN and the EU. If the ratio of potential trade to actual trade is higher than 1, there exists undiscovered trade potential between ASEAN and the EU.

The potential trade is projected by applying equation (3) to each of the country pairs between the four EU members and the six ASEAN members for the period of 1994 to 2008 . Then the estimated potential trade is divided by the actual trade to assess the undiscovered trade potential.

Figure 3(a) in appendix 1 presents the trade potential between France-ASEAN country pairs. For the France-Singapore pair, the estimated trade potential for both exports and imports are downward. It indicates that the ongoing integration process decreases the gap between the potential trade and the actual trade, though the undiscovered trade potential is still substantial. For the rest of the country pairs, the import potential is downward, which is substantially visible for the France-Viet 
Nam pair. On the other hand, export potential is upward, which is substantial in the France-Indonesia pair and insubstantial for the France-Philippines pair. In all cases, the amount of undiscovered potential trade is substantial. This suggests that ASEAN exports to France increase from the process of trade integration, and there exists substantial scope for further trade enhancement. On the other hand, French exports to ASEAN are much lower than the potential level, and the gap is progressively increasing.

Figure 3(b) in appendix 1 presents the trade potential between Germany-ASEAN country pairs. For Germany-Singapore, Germany-Malaysia and Germany-Viet Nam pairs, the trends for the estimated trade potential for both exports and imports are downward. This indicates a decreasing trend in the gap between the potential trade and the actual trade, while the undiscovered trade potential is quite substantial. The Germany-Thailand and Germany-Philippines pairs show a downward trend of imports potential, while the exports potential is almost unchanged. This suggests that these two ASEAN members' exports to Germany have substantially increased in the trade integration process, while the process fails to have had a significant influence on Germany's exports to Thailand and the Philippines. Similarly, Indonesia has been able to realize some of the export potentials in the last few years, while Germany's gap between potential trade and actual trade has increased during that period. The scope existing for further trade enhancement is substantial for all six country pairs.

Figure 3(c) in appendix 1 presents the trade potential between Italy-ASEAN country pairs. The exports trend for Italy-Singapore is unchanged, while the import trend is upward. This indicates that the integration process has not been able to have any impact on Italy's exports to Singapore, while the gap between Singapore's potential trade and actual trade has increased over time. Similarly, the integration process shows negligible impact on Italian exports to Thailand and the Philippines, and Italian imports to Philippines. On the other hand, Italian imports to Thailand are found to have a downward trend, indicating Thailand's achievement of exports gain to Italy from the extra-regional trade integration. For ItalyIndonesia and Italy-Malaysia, the exports potential trend is upward while the imports potential trend is downward. This trend suggests that the gap between Italian potential exports and actual exports has increased over time, while the gaps between Indonesian and Malaysian potential exports and actual exports to Italy have decreased, indicating substantial export gain for Indonesia and Malaysia from the trade integration process. On the contrary, both Italy and Viet Nam enjoy 
exports gains from their trade relations.

In the Spain-ASEAN trade relationship presented at Figure 3(d) in appendix 1, the gap between potential exports and actual exports has substantially increased over time for the Spain-Singapore pair, while the gap is almost unchanged for the Spain-Indonesia and Spain-Thailand pairs. The similar imports gaps of all three country pairs are significantly downward. This indicates that Singapore, Indonesia and Thailand have achieved export gains with Spain from the trade integration process, while Spain has failed to achieve any export gain with these three ASEAN members. On the other hand, the rest of the three country pairs show a downward trend in the gap between potential trade and actual trade for both exports and imports, though the rate of change for Spain-Viet Nam is insignificant. This trend suggests that Spain has achieved exports gains with Malaysia, Philippines and Viet Nam and vice versa, which has occurred as a result of ASEAN-EU trade integration. In all cases, the existence of substantial undiscovered trade potential is evident for these countries.

The above analysis identifies substantial exports gains for most of the ASEAN members in the ASEAN-EU trade integration process, while exports gains for the EU members are inferior. In both cases, the existence of substantial undiscovered trade potential is evident in the ASEAN-EU trade integration.

\section{A comparison with European trade integration}

In their paper, Pastore, Ferragina and Giovannetti (2009) estimate the trade potential of the Mediterranean countries (MED) and the Central and Eastern European (CEE) Countries with four European Union members, namely France, Germany, Italy and Spain. Similarly, this paper investigates the trade potential of ASEAN members with the same set of EU members using the same intra-EU model. This method provides scope for a comparison of ASEAN members' trade potential with the MED and the CEE members' trade potential.

Pastore, Ferragina and Giovannetti (2009) show that the ratios of potential trade to actual trade between EU and MED are in between 3.5 to 5 for both exports and imports, which means that actual trade between these two groups of countries is about $20 \%$ to $30 \%$ of potential trade. For the same period, the ratios of potential trade to actual trade between EU and CEECs are between 2 to 2.6 for both exports and imports, which mean that the actual trade between these two groups of countries is about $40 \%$ to $50 \%$ of potential trade. This paper shows that the ratios of potential trade to actual trade between EU and ASEAN is between 2 to 2.5 for 
both exports and imports, which means that the actual trade between these two groups of countries is about $40 \%$ to $50 \%$ of potential trade. This shows that the ASEAN members have been able to achieve an equivalent trade gain to the CEECs' through a de facto regional trade integration process with the European Union. Introduction of a de jure trade integration process would raise the level of ASEAN integration success above the CEECs'.

\section{Conclusion}

This paper investigates ASEAN-EU trade potential by comparing the actual trade to the estimated potential trade. This assessment comes from comparison with a benchmark created from intra-EU trade integration. This benchmark is obtained from a gravity model structured for the EU-members. The estimates of coefficients of the gravity model are considered as the standard value of elasticity for the ASEAN-EU trade integration model. Application of these standard values to the ASEAN-EU trade model returns the potential trade that would be made possible if ASEAN members had regional trade integration at a level similar to that of the EU members. The undiscovered trade potential of the ASEAN-EU trade integration is estimated from the ratio of the projected potential trade to actual trade between four EU members and six ASEAN members.

The empirical results show that there is a substantial undiscovered potential trade exists between ASEAN and the EU. The gap between potential ASEAN exports and the actual ASEAN exports towards the EU has substantially decreased over time, while decrease in the gap between potential EU exports and the actual EU exports towards ASEAN has been slow. The level of ASEAN trade integration with the European Union is at the level of the EU-CEEC trade integration and at the higher level than the EU-MED trade integration.

The findings of this paper provide some important policy directions. Firstly, ASEAN de facto trade integration with the European Union achieves a high level of success. Secondly, there is the possibility for even higher levels of integration success with a de jure ASEAN-EU trade integration process. Thirdly, ASEAN is as important a trade partner as the CEECs for the European Union. This paper initiates an important step towards the empirical study of ASEAN-EU trade integration. Further research on the topic would provide a better view of the issue. The benchmark model used in this paper covers the period of 1995 to 2002 . Extension of this observation period would provide a deeper analytical review of 
the trade potential, which was out of scope of this paper.

Received 3 February 2011, Revised 18 July 2011, Accepted 19 July 2011

\section{References}

Anderson, J. E. (1979), A Theoretical Foundation for the Gravity Equation. American Economic Review, 69(1), pp. 106-16.

Anderson, J. E., and E. V. Wincoop. (2003), Gravity with Gravitas: A Solution to the Border Puzzle. American Economic Review, 93(1), pp. 170-92.

Andreosso-O'Callaghan, B. (2009), How is the EU-ASEAN FTA viewed by ASEAN stakeholders? Asia Europe Journal, 7(1), pp. 63-78.

ASEAN Secretariat. (2008a), Selected basic ASEAN indicators. http://www.aseansec.org/ stat/Table1.pdf (accessed April 24, 2010).

ASEAN Secretariat. (2008a), Selected basic ASEAN indicators. http://www.aseansec.org/ stat/Table1.pdf (accessed June 24, 2009).

ASEAN Secretariat. (2008b), Selected key ASEAN macroeconomic indicators. http:// www.aseansec.org/stat/Table2.pdf (accessed June 24, 2009).

Bayoumi, T., and B. Eichengreen. (1997), Ever Close to Heaven? An Optimum-CurrencyArea Index for European Countries. European Economic Review, 41(3-5, April), pp. 761-70.

Berger, H., and V. Nitsch. (2008), Zooming out: The trade effect of the euro in historical perspective. Journal of International Money and Finance, 27(8), pp. 1244-60.

Bergstrand, J. (1985), The Gravity Equation in International Trade: Some Microeconomic Foundations and Empirical Evidence. Review of Economics and Statistics, 67(3), pp. 474-81.

Bergstrand, J. (1989), The Generalized Gravity Equation, Monopolistic Competition, and the Factor-Proportions Theory in International Trade. Review of Economics and Statistics, 71(1), pp. 143-53.

Candelona, B., J. Piplacka, and S. Straetmansb. (2008), On measuring synchronization of bulls and bears: The case of East Asia. Journal of Banking \& Finance, 32(6), pp. 1022-35.

Capannelli, G., and C. Filippini. (2010), Economic Integration in East Asia and Europe: Lessons from a Comparative Analysis. The Singapore Economic Review, 55(1), pp. $163-84$.

Chia, S. Y. (2011), Association of Southeast Asian Nations Economic Integration: Developments and Challenges. Asian Economic Policy Review, 6(1), pp. 43-63.

Chia, S. Y. (2007), Whither East Asian Regionalism? An ASEAN Perspective. Asian Economic Papers, 6(3), pp. 1-36.

Click, R. W., and M. G. Plummer. (2005), Stock market integration in ASEAN after the Asian financial crisis. Journal of Asian Economics, 16(1), pp. 5-28. 
Deardorff, V. A. (1998), Determinants of Bilateral Trade: Does Gravity Work in a Neoclassical World? In The Regionalization of Economy, ed. J. A. FrankelChicago: University of Chicago Press. National Bureau of Economic Research Project Report Dutta, M. (2002), Asian Economic Community: Intra-community macro-and-microeconomic parameters. Journal of Asian Economics, 13, pp. 447-91.

Eaton, J., and S. Kortum. (2002), Technology, Geography, and Trade. Econometrica, 70 (5), pp. 1741-79.

Gavin, B., and A. Sindzingre. (2009), EU trade relations with Emerging Asia: identifying the issues. Asia Europe Journal, 7(1), pp. 9-22.

Glick, R., and A. Rose. (2002), Does a currency union affect trade? The time-series evidence. European Economic Review, 46(6), pp. 1125-51.

Hashmi, S. M., and Y. T. Lee. (2008), Towards East Asian Economic Integration. European Journal of Economics, Finance and Administrative Sciences, (12), pp. 11622.

Helpman, E., and P. Krugman. (1985), Market Structure and Foreign Trade: Increasing Returns, Imperfect Competition and the International Economy. Cambridge, Mass.: MIT Press.

Kawai, M. (2005), East Asian economic regionalism: progress and challenges. Journal of Asian Economics, 16(1), pp. 29-55.

Kimura, F., and H.-H. Lee. (2006), The Gravity Equation in International Trade in Services. Review of World Economics, 142(1), pp. 92-121.

Kumakura, M. (2006), Trade and business cycle co-movements in Asia-Pacific. Journal of Asian Economics, 17(4), pp. 622-45.

Lee, J.-W., K. Shin, and Y. Park. (2004), A Currency Union in East Asia. In Monetary and Financial Integration in East Asia: The Way Ahead, ed. A. D. Bank: Palgrave MacMillan.

Madhur, S. (2002), Cost and Benefit of a Common Currency for ASEAN. ERD working paper 12. http://www.adb.org/Documents/ERD/workingpaper/wp012.pdf (accessed 05 June 2009). Asian Development Bank.

Nardis, S. D., and C. Vicarelli. (2003), The Impact of the Euro on Trade The (Early) Effect Is Not So Large. European Network of Economic Policy Research Institutes (working paper no. 17/february 2003).

Ong, K. Y. (2007), ASEAN Community Building: Challenges \& Prospects, SingaporeanGerman Chamber of Industry and Commerce Monthly Luncheon, Singapore, 27 November 2007.

Ong, K. Y. (2008), One ASEAN: a partner for Europe. Asia Europe Journal, 5(4), pp. 443-45.

Pastore, F., A. M. Ferragina, and G. Giovannetti. (2009), A Tale of Parallel Integration Processes: A Gravity Analysis of EU Trade with Mediterranean and Central and Eastern European Countries. Review of Middle East Economics and Finance, 5(2).

Pomfret, R. (2007), Is Regionalism an Increasing Feature of the World Economy? The World Economy, 30(6), pp. 923-47.

Pöyhönen, P. (1963), A Tentative Model for the Volume of Trade between Countries. 
Weltwirtschaftliches Archiv/Review of World Economics, 90(1), pp. 93-100.

Rana, P. B. (2006), Economic Integration in East Asia: Trends, Prospects, and a Possible Roadmap. Working Paper Series on Regional Economic Integration 2 (July). Office of Regional Economic Integration, Asian Development Bank.

Richardson, M. (2005), Australia-Southeast Asia relations and the East Asian Summit. Australian Journal of International Affairs, 59(3), pp. 351-65.

Robles, A. C. (2008), THE EU AND ASEAN Learning from the Failed EU-Mercosur FTA Negotiations. ASEAN Economic Bulletin, 25(3), pp. 334-344.

Rose, A. K. (2000), One Money, One Market: The Effect of Common Currencies on Trade. Economic Policy, 15(30), 9-45. Blackwell Publishing on behalf of the Centre for Economic Policy Research, Center for Economic Studies, and the Maison des Sciences de l'Homme.

Salim, R., and S. Kabir. (2010), The Immediate Impact of Euro on Intra-Regional Trade: An Event Study Approach. Journal of Economic Development, 35(3), pp. 43-55.

Sally, R., and R. Sen. (2005), Whither trade policies in Southeast Asia? The wider Asian and global context. ASEAN Economic Bulletin, 22(1), pp. 92-115.

Sally, R. (2006), Trade policy 2006. A tour d'horizon. World Economics, 7(1), pp. 45-71.

Sen, R. (2006), "New Regionalism" in Asia: A comparative analysis of emerging regional and bilateral trading agreements involving ASEAN, China and India. Journal of World Trade, 40(4), pp. 553-96.

Tinbergen, J. (1962), Shaping the World Economy-Suggestions for an International Economic Policy. New York: The Twentieth Century Fund.

Wang, Y. (2004), Financial cooperation and integration in East Asia. Journal of Asian Economics, 15(5), pp. 939-55. 


\section{Appendix}

Figure 3 (a). France-ASEAN trade potential
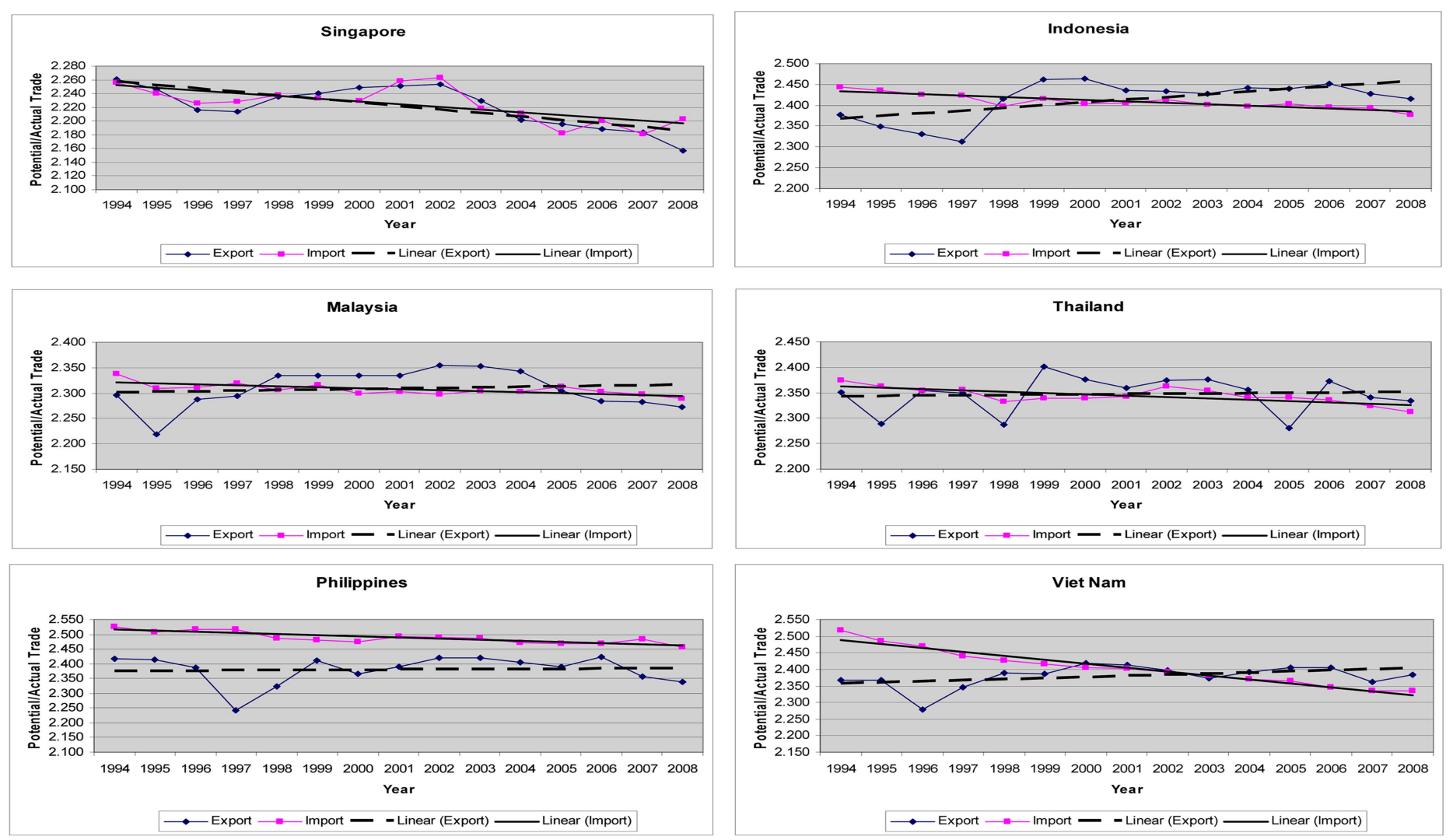
Figure 3 (b). Germany-ASEAN trade potential
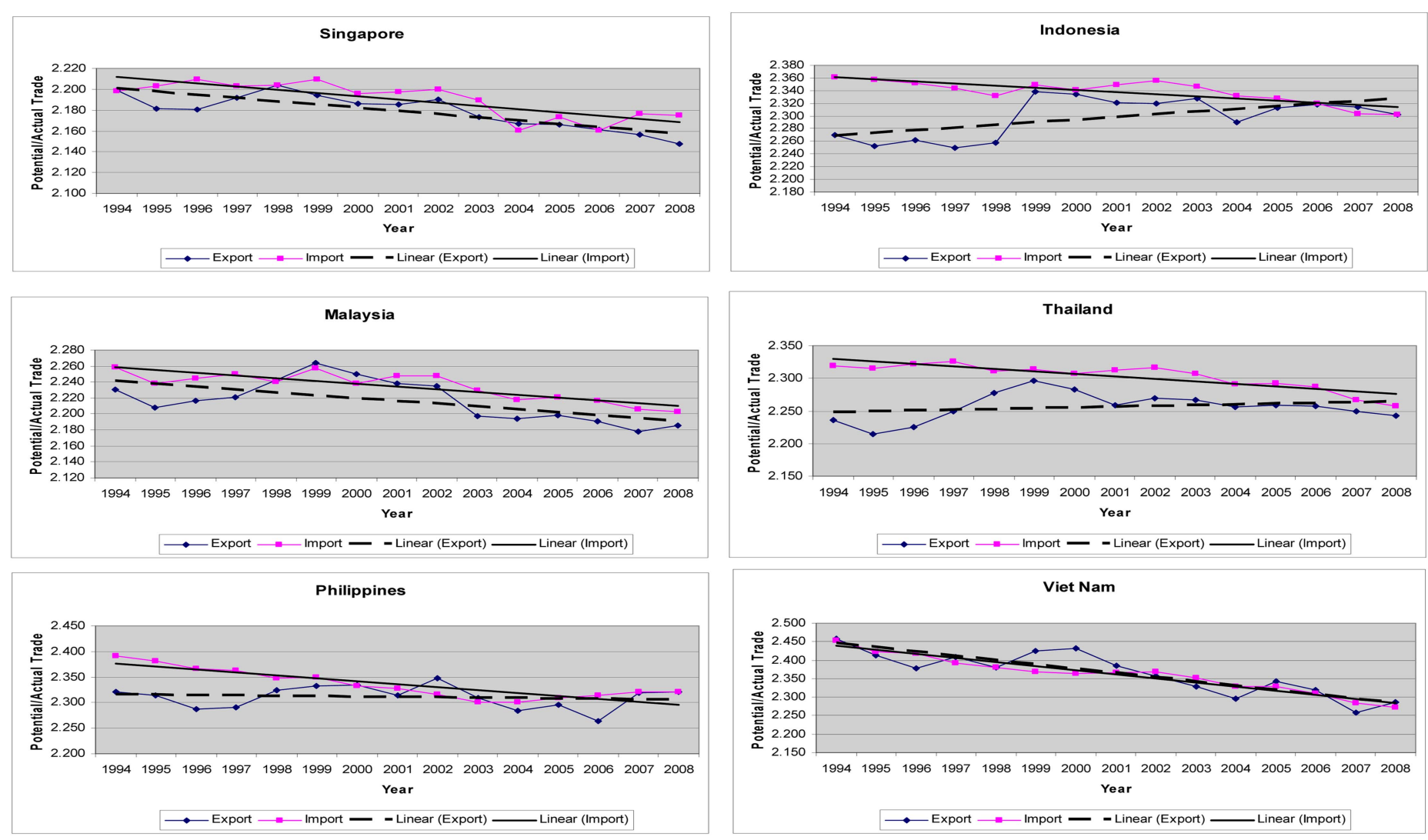
Figure 3 (c). Italy-ASEAN trade potential
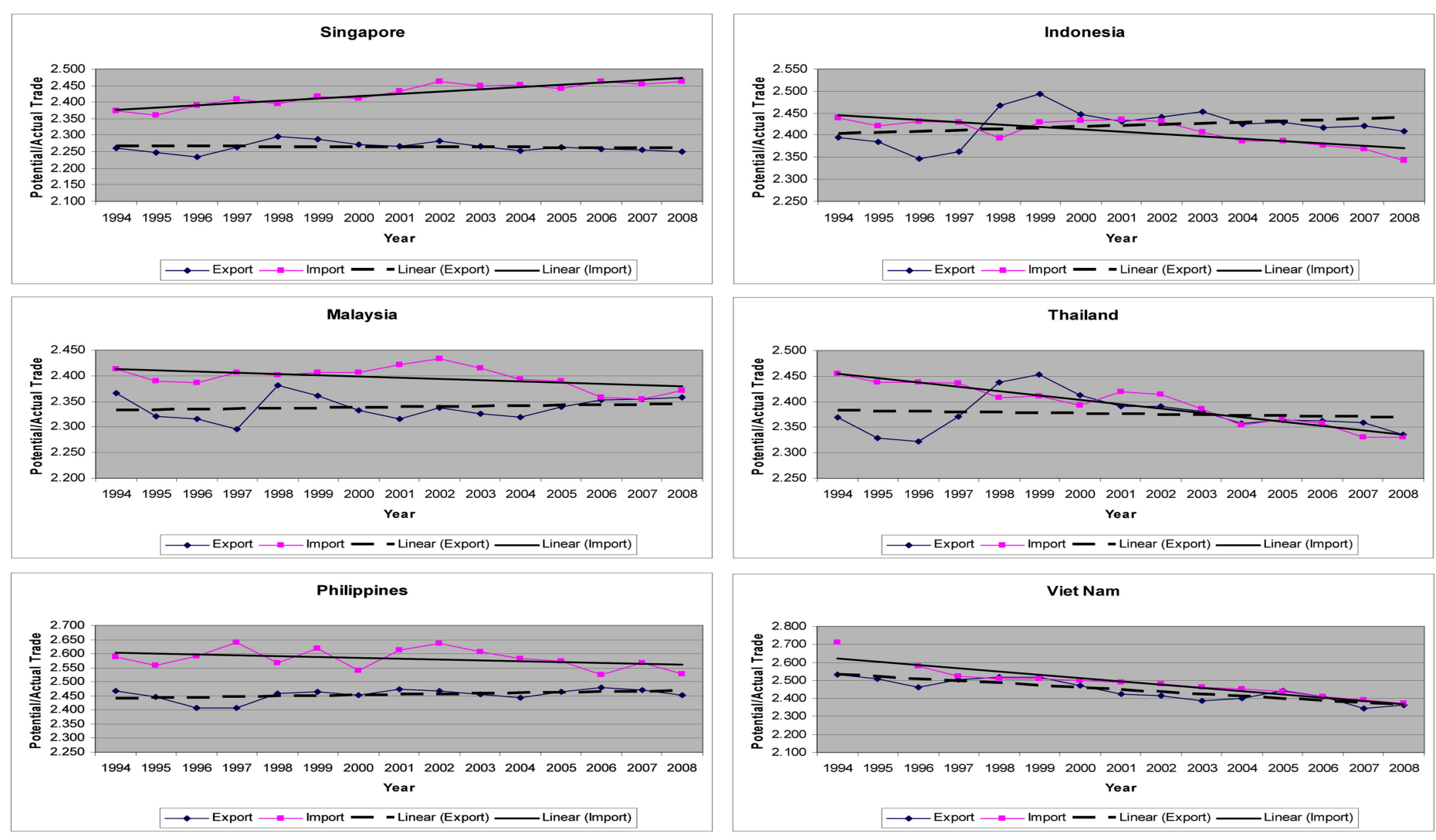
Figure 3 (d). Spain-ASEAN trade potential
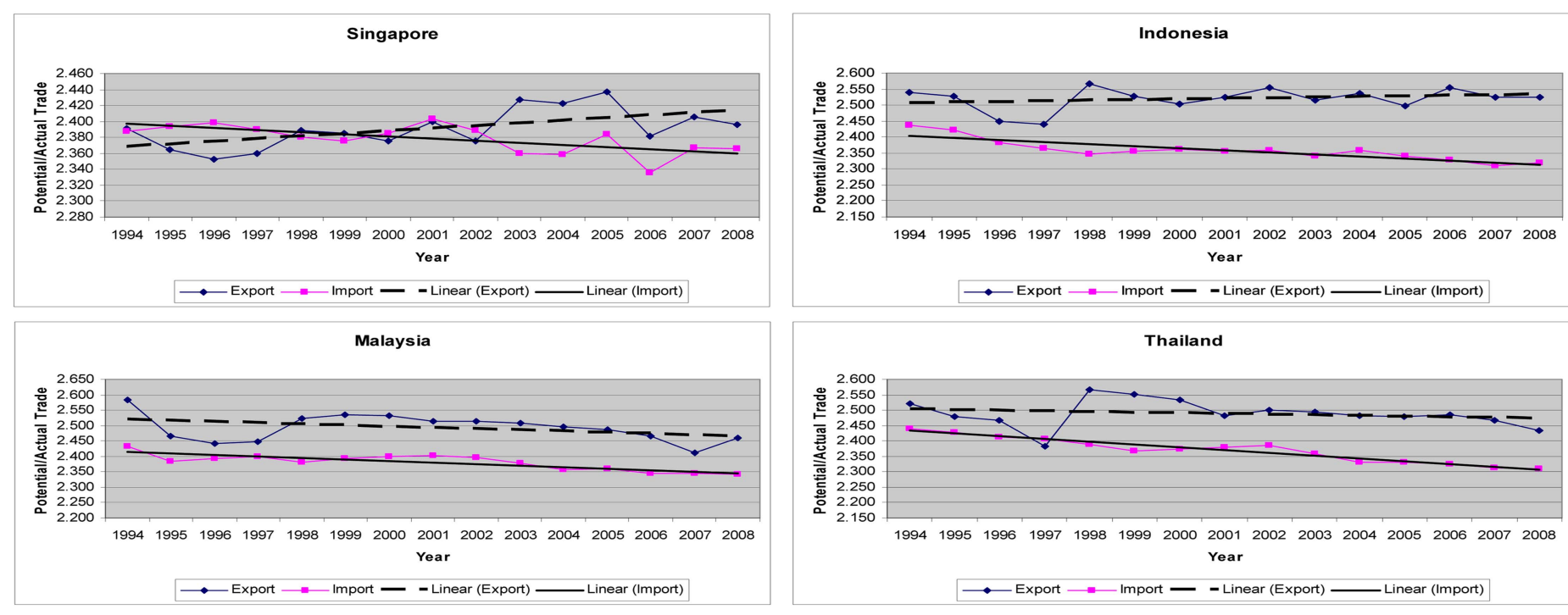

Philippines
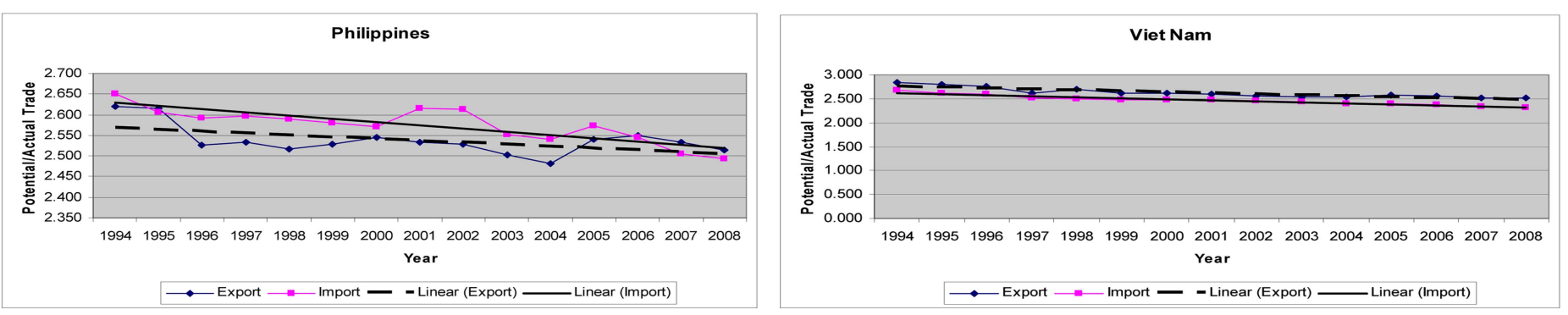